\title{
ANALISIS REGRESI DATA PANEL PADA FAKTOR-FAKTOR YANG MEMPENGARUHI KEMISKINAN DI INDONESIA TAHUN 2015 - 2019
}

\author{
Nadiya Aulina ${ }^{1}$, Mirtawati \\ Universitas Islam As-Syafi'iyah \\ Jln. Raya Jatiwaringin No. 12, Jakarta Timur, 13077 \\ Telp : 021-98297211/02191274243, Fax : 021- 8484719 \\ e-mail : nanadaul@gmail.com ${ }^{1}$, mirta.mulyami@gmail.com²
}

\begin{abstract}
Abstrak
Indonesia merupakan negara dengan tingkat kemiskinan yang tinggi karena banyaknya jumlah penduduk miskin, menunjukkan proses pembangunan ekonomi yang belum bisa meningkatkan kesejahteraan rakyatnya. Untuk mengatasi masalah kemiskinan tersebut, terlebih dahulu perlu dilakukan analisis faktor-faktor apa saja yang mempengaruhi kemiskinan. Tujuan dari penelitian ini adalah untuk mengetahui faktor-faktor yang berpengaruh terhadap tingkat kemiskinan di Indonesia tahun 2015-2019. Penelitian ini menggunakan data sekunder dengan metode analisis regresi data panel, yang terdiri dari data time series selama periode 2015-2019 dan data cross section 33 provinsi di Indonesia dengan bantuan program Eviews 9. Hasil penelitian menunjukkan bahwa variabel pertumbuhan ekonomi (PDRB) berpengaruh negatif dan signifikan serta variabel tingkat pengangguran terbuka berpengaruh positif dan signifikan terhadap tingkat kemiskinan di Indonesia tahun 2015-2019. Model regresi diperoleh dari estimasi Ordinary Least Square dengan pendekatan fixed effect model menggunakan variabel dummy untuk mengetahui perbedaan intersep masing-masing provinsi yang menjelaskan efek perbedaan wilayah. Provinsi DKI Jakarta, Kep. Riau, dan Kalimantan Timur terdampak negatif faktor-faktor kemiskinan dan Provinsi Papua, Papua Barat, dan Nusa Tenggara Timur terdampak positif faktor-faktor kemiskinan.
\end{abstract}

Kata Kunci: Kemiskinan, PDRB, Regresi Data Panel, Model Fixed Effect

\begin{abstract}
High rate of poverty in Indonesia is shown by the large number of poor people. This condition means that the economic development is not still be able to increase the walfare of the people. First, we need to analyze which factors that might be able to significantly affect the rates of poverty. The goal of this research is to determine those factors in Indonesia from 2015-2019. Secondary data is used in this research along with Data Panel Regression Analysis that is consisted of time series data in range 2015-2019 and cross section data of 33 provinces in Indonesia that is processed by Eviews 9. The regression model is obtained from Ordinary Least Square estimation through fixed effect model approach using dummy variable to find out different intercept in each provinces which explaining different area. The result show that the economic growth is significantly and negatively affecting the poverty in Indonesia from 2015 to 2019. DKI Jakarta, Riau Islands, and East Kalimantan negatively affected to the factors of poverty while Papua, West Papua, and East Nusa Tenggara positively affected.
\end{abstract}

Key Word: Poverty, PDRB, Literacy Rate, Fixed Effect Model 


\section{PENDAHULUAN}

Indonesia merupakan negara yang memiliki tujuan memajukan kesejahteraan umum. Hal ini termaktub dalam Pembukaan Undang-Undang Dasar 1945. Kesejahteraan umum merupakan kondisi terpenuhinya kebutuhan material, spiritual, dan sosial penduduk negara agar dapat hidup layak dan mampu mengembangkan diri, sehingga dapat melaksanakan fungsi sosial dan ekonominya (Badan Pusat Statistik, 2000). Berdasarkan definisi tersebut, kesejahteraan umum pada suatu wilayah dapat dilihat dari tingkat kemiskinan penduduknya.

Untuk meningkatkan kesejahteraan umum berbagai pembangunan nasional dilakukan. Dapat di mulai dari pembangunan tak berwujud seperti peningkatan sumber daya manusia maupun berwujud seperti peningkatan infrastruktur yang merata, khususnya pada wilayah Indonesia timur seperti Maluku dan Papua yang rata-rata memiliki tingkat kesejahteraan rendah. Pembangunan nasional di Indonesia dilakukan berdasarkan Undang-Undang Nomor 25 Tahun 2004 tentang Sistem Perencanaan Pembangunan Nasional yang dijalankan sesuai dengan kondisi masing-masing daerah serta skala prioritas secara terpadu dan berkelanjutan. Pembangunan nasional dinilai berhasil apabila jumlah penduduk miskin di Indonesia berkurang dan meningkatnya kesejahteraan masyarakat.

Kemiskinan adalah salah satu permasalahan umum yang dialami oleh negara berkembang seperti Indonesia. Dibandingkan dengan negara tetangga seperti Malaysia dan Brunei, pendapatan per kapita Indonesia masih terlampau jauh dari kedua negara tersebut. Pemerintah tentunya telah melakukan berbagai upaya dalam mengatasi permasalahan ini yang telah mengakar dari zaman ke zaman. Kebijakan-kebijakan pemerintah untuk mengatasi kemiskinan masih terus menerus dikaji sampai saat ini.

Kurangnya pendapatan dan aset di Indonesia adalah salah satu sebab kemiskinan (lack of income and assets) untuk memenuhi kebutuhan dasar seperti makanan, pakaian, perumahan, dan tingkat kesehatan serta pendidikan yang dapat diterima (Wishnu Adhi Saputra, 2011). Kemiskinan yang terjadi di Indonesia terkait erat dengan indikatorindikator lain seperti tingkat pengangguran, tingkat pendidikan dan tingkat kesehatan. Tingginya tingkat kemiskinan biasanya diikuti oleh tingginya angka pengangguran serta rendahnya tingkat pendidikan dan kesehatan.

Pemerintah perlu memperhatikan tingginya angka penduduk miskin di Indonesia. Dengan demikian, untuk menghindari semakin tingginya tingkat kemiskinan di wilayah $3 \mathrm{~T}$ (Tertinggal, Terdepan dan Terluar) diperlukan metode-metode dan strategi yang tepat dalam upaya pengentasan kemiskinan tersebut. Penelitian lebih lanjut untuk menanggulangi masalah kemiskinan di Indonesia menjadi sangat penting untuk dilakukan.

Analisis regresi data panel merupakan pengembangan dari regresi linier dengan metode OLS yang memiliki kekhususan dari segi jenis data dan tujuan analisisnya. Metode analisis regresi data panel merupakan metode yang tepat digunakan untuk menganalisis faktor-faktor yang mempengaruhi tingkat kemiskinan di Indonesia karena 
data panel merupakan gabungan dari data cross section dan data time series sehingga mempunyai observasi yang lebih banyak dibanding data cross section dan data time series saja.

Ada 3 pendekatan yang dapat digunakan dalam mengestimasi model regresi data panel, yaitu model efek umum, model efek tetap, dan model efek acak (Fitrianingsih, 5). Pada model efek umum, estimasi parameter menggunakan metode Ordinary Least Square (OLS), pada model efek tetap estimasi parameter dengan menggunakan OLS melalui penambahan variabel boneka (dummy variabel), sedangkan pada model efek acak estimasi parameter dilakukan dengan menggunakan Generalized Least Square (GLS), dengan galat atau error diasumsikan acak/random. Mempertimbangkan keragaman yang terjadi dalam unit cross section dan lebih informatif daripada time series sederhana secara keseluruhan merupakan keuntungan dengan menggunakan analisis regresi data panel.

\section{TINJAUAN PUSTAKA}

\section{Kemiskinan}

Kemiskinan merupakan konsep yang komprehensif dengan lima tingkatan sebagai perangkapnya, yaitu (1) kemiskinan itu sendiri, (2) ketidakberdayaan, (3) kerentanan terhadap keadaan darurat, (4) ketergantungan, dan (5) isolasi geografis dan sosiologis (Robert Chamber, 2010).

Kemiskinan merupakan salah satu penyakit dalam perekonomian suatu negara, terutama di negara berkembang. Dimana masalah kemiskinan sangat kompleks dan beraneka ragam. Kemiskinan itu kompleks, artinya kemiskinan tidak muncul secara tibatiba, tetapi memiliki latar belakang yang panjang dan kompleks, sehingga sulit untuk mengetahui akar penyebab dari masalah kemiskinan itu sendiri. Kemiskinan yang bersifat beraneka ragam artinya dari keragaman kebutuhan manusia.

\section{Pertumbuhan Ekonomi}

Salah satu indikator yang digunakan untuk mengatur tingkat kemakmuran daerah adalah pertumbuhan ekonomi. Pertumbuhan ekonomi yang berkualitas tinggi mengacu pada pertumbuhan ekonomi yang bertujuan untuk menciptakan lapangan kerja dan mendukung pengentasan ekonomi.

Pertumbuhan ekonomi biasanya dihitung berdasarkan tahun tertentu dan dinyatakan dalam persen berdasarkan tahun sebelumnya. Menurut keterangan dari BI, saat ini pertumbuhan ekonomi di Indonesia stabil di angka 5\% secara keseluruhan.

\section{Indeks Pendidikan}

Indeks pendidikan dipengaruhi oleh dua faktor, yaitu Angka Melek Huruf dan Rata-Rata Lama Sekolah. Berikut rumusnya untuk menghitung tingkat melek huruf :

$$
\mathrm{AMH}=\frac{\text { Jumlah Penduduk } 15 \text { tahun ke atas }}{\text { Total Jumlah Penduduk }} \times 100 \%
$$


Sedangkan untuk rata-rata lama sekolah :

$$
\mathrm{RLS}=\frac{1}{n} x \sum_{i=1}^{n} x_{i}
$$

Pendidikan merupakan hal mendasar yang sangat berpengaruh terhadap kelangsungan suatu negara. Pemerintah telah menetapkan bahwa pendidikan adalah salah satu tujuan negara. Hal ini tertuang dalam Pasal 31 UUD 1945 tentang pendidikan.

\section{Tingkat Pengangguran Terbuka}

Kemiskinan sering dikaitkan dengan pekerjaan. Secara kasar, orang yang tidak memiliki pekerjaan atau belum dapat pekerjaan biasanya disebut sebagai orang yang sedang mengalami kemiskinan. Nilai tingkat pengangguran terbuka dapat dilihat dengan membandingkan jumlah pencari kerja atau pengangguran dengan jumlah angkatan kerja. Tingkta pengangguran terbuka ini sangat penting dalam melihat kinerja pemerintah dalam menanggulangi kemiskinan.

\section{Indeks Pembangunan Manusia}

Indeks pembangunan manusia merupakan suatu indikator yang digunakan untuk melihat baik atau buruknya kualitas hidup manusia. Indikator ini didasari oleh tiga aspek, yaitu aspek kesehatan, aspek pendidikan, dan aspek pengeluaran masyarakat.

\section{METODE PENELITIAN}

\section{Sumber Data dan Variabel Penelitian}

Jenis data pada penelitian ini adalah data sekunder yang diambil dari situs resmi Badan Pusat Statistik Indonesia. Adapun data yang diambil adalah data tingkat kemiskinan di seluruh provinsi di Indonesia (kecuali Provinsi Kalimantan Utara) pada tahun 2015-2019. Selain itu, dari situs yang sama, diperoleh pula data mengenai faktorfaktor yang mempengaruhi kemiskinan tersebut, seperti pertumbuhan ekonomi, angka melek huruf, rata-rata lama sekolah, pengangguran terbuka, dan indeks pembangunan manusia. Dalam penelitian ini, variabel yang akan digunakan adalah Tingkat kemiskinan $(Y)$, Pertumbuhan ekonomi $\left(X_{1}\right)$, Angka melek huruf $\left(X_{2}\right)$, Rata-rata lama sekolah $\left(X_{3}\right)$, Tingkat pengangguran terbuka $\left(X_{4}\right)$, dan Indeks pembangunan manusia $\left(X_{5}\right)$.

\section{Metode Analisis}

Data panel merupakan gabungan dari data runtun waktu dan data cross section. Data panel ini digunakan untuk mengetahui faktor-faktor yang signifikan berdasarkan pengamatan yang berulang-ulang pada suatu objek dalam waktu yang berbeda. Para ahli statistik sering menggunakan metode ini untuk mengetahui bagaimana suatu faktor memiliki pengaruh terhadap permasalahan tertentu secara periodik seperti kemiskinan, likuiditas saham, keuntungan penjualan, dan sebagainya. Regresi data panel merupakan pengembangan dari regresi linier berganda. Keduanya sama-sama digunakan untuk memprediksi parameter model regresi. Pendekatan yang digunakan untuk mengestimasi model regresi data panel yaitu: 
1. Common Effect Model (Model Efek Umum)

Model ini merupakan model yang paling sederhana dalam regresi data panel. Model ini menggunakan Ordinary Least Squares (OLS) dalam menggabungkan data cross section dan runtun waktu dalam mengestimasi parameter regresi (Baltagi, 2005). Common Effect Model memiliki bentuk sebagai berikut :

$$
Y_{i t}=\alpha+\beta_{j} X_{i t}^{j}+\varepsilon_{i t}
$$

dengan,

$Y_{i t} \quad$ : variabel dependen untuk objek ke- $i$ pada periode ke- $t$

$X_{i t} \quad$ : variabel independen ke- $j$ untuk objek ke- $i$ pada periode ke- $t$

$\varepsilon_{i t} \quad$ : galat untuk objek ke- $i$ pada periode ke- $t$

$\alpha \quad$ : intersep model regresi

$\beta_{j} \quad$ : parameter untuk variabel ke-j

\section{Fixed Effect Model (Model Efek Tetap)}

Asumsi dari model ini adalah terdapat pengaruh yang berbeda antar objek. Pada model ini perbedaan karakteristik objek dan periode diakomodasikan pada intersep sehingga intersepnya berubah terhadap periode. Fixed Effect Model menggunakan variabel boneka sebagai pengestimasi parameter yang tidak diketahui sehingga disebut juga Least Square Dummy Variable (LSDV) Model. Fixed Effect Model memiliki persamaan sebagai berikut :

$$
Y_{i t}=\alpha_{i}+\beta_{j} X_{i t}^{j}+\sum_{i=2}^{n} \alpha_{i} D_{i}+\varepsilon_{i t}
$$

Keterangan:

$Y_{i t} \quad$ : variabel dependen untuk objek ke-i pada periode ke- $t$

$X_{i t}^{j} \quad$ : variabel independen ke- $j$ untuk objek ke- $i$ pada periode ke- $t$

$D_{i} \quad$ : variabel boneka

$\varepsilon_{i t} \quad$ : galat untuk objek ke- $i$ pada periode ke- $t$

$\alpha_{i} \quad$ : intersep model regresi

$\beta_{j} \quad$ : parameter untuk variabel ke- $j$

3. Random Effect Model (Model Efek Acak)

Model ini mengasumsikan bahwa pengaruh objek bersifat acak atau random bagi seluruh cross section. Berbeda dengan Fixed Effect Model, perbedaan karakteristik objek dan periode diakomodasikan oleh galat (Nachrowi dan Usman, 2006). Random Effect Model diformulasikan sebagai berikut (Gujarati, 2012) :

$$
Y_{i t}=\alpha_{i}+\beta X_{i t}+\varepsilon_{i t}
$$


dimana $\varepsilon_{i t}=u_{i}+v_{t}+w_{i t}$

Keterangan:

$u_{i} \quad$ : galat pada pengamatan ke-i

$v_{t} \quad$ : galat pada pengamatan ke- $\mathrm{t}$

$w_{i t} \quad$ : galat gabungan

Penelitian ini di dukung dengan menggunakan software Eviews 9. Langkah-langkah yang dilakukan pada penelitian ini sebagai berikut :

1. Pemilihan model terbaik

\section{a. Uji Chow}

Uji ini digunakan untuk memilih model terbaik antara FEM dan CEM. Pemilihan ini didasarkan pada perbandingan nilai $F_{\text {hitung }}$ dan $F_{\text {tabel }}$. Apabila nilai $F_{\text {hitung }}>F_{\text {tabel }}$, maka model yang dipilih adalah FEM.

b. Uji Hausman

Uji ini digunakan untuk memilih model terbaik antara FEM dan REM. Dasar pemilihannya adalah dengan membandingkan nilai $\chi_{\text {hitung }}^{2}$ dan $\chi_{\text {tabel }}^{2}$. Apabila nilai $\chi_{\text {hitung }}^{2}<\chi_{\text {tabel }}^{2}$, maka model yang dipilih adalah REM.

\section{Uji Asumsi Klasik}

Persamaan yang diperoleh dari sebuah estimasi dapat dioperasikan secara statistik memenuhi asumsi klasik, yaitu memenuhi asumsi bebas multikolineritas, heteroskedastisitas, autokorelasi, serta terdistribusi secara normal.

3. Uji Signifikansi

Uji signifikansi merupakan prosedur yang digunakan untuk melihat baik atau tidaknya model regresi yang telah dibuat. Uji ini terdiri dari uji $F$, uji $t$, dan koefisien determinasi

4. Menarik kesimpulan dari model regresi data panel untuk faktor-faktor yang berpengaruh terhadap tingkat kemiskinan di Indonesia berdasarkan hasil yang diperoleh dari analisis regresi data panel. 
KINERJA Jurnal Ekonomi dan Bisnis

Vol. 4 No. 1 - Desember 2021

\section{HASIL PENELITIAN}

\section{Analisis Model}

Analisis regresi data panel digunakan pada variabel-variabel independen dan variabel dependen dengan software eviews 9. Berikut merupakan hasil dari masingmasing model.

\begin{tabular}{crrrr}
\hline \hline Variable & Coefficient & Std. Errot & 1.Statistic & Prob \\
\hline \hline C & 2015.098 & 2.642120 & 762.6823 & 0.0000 \\
X1? & 0.002690 & 0.011143 & 0.242253 & 0.8089 \\
X2? & -0.047516 & 0.047762 & -0.994880 & 0.3213 \\
X3? & -0.017917 & 0.029267 & -0.612214 & 0.5413 \\
X4? & 0.448785 & 0.156940 & 2.859590 & 0.0048 \\
X5? & -0.082898 & 0.033030 & -2.509757 & 0.0131 \\
\hline R-squared & 0.071395 & & & \\
\hline
\end{tabular}

Gambar 1. Hasil perhitungan CEM

Persamaan hasil regresi data panel dengan metode common effect model :

$\mathrm{PPM}=2015,098+0,002699 \mathrm{PDRB}-0,047516 \mathrm{AMH}-0,017917 \mathrm{RLS}+0,448785 \mathrm{TPT}$ $-0,082898$ IPM

\begin{tabular}{lrlll}
\hline \hline R-squared & 0.922000 & Mean dependent var & 2016.000 \\
Adjusted R-squared & 0.899276 & S.D. dependent var & 1.418519 \\
SE of regression & 0.450196 & Akaike info criterion & 1.440580 \\
Sum squared resid & 25.73989 & Schwarz criterion & 2.155888 \\
Log likelihood & -80.84782 & Hannan-Quinn criter. & 1.730948 \\
F-statistic & 40.57330 & Durbin-Watson stat & 1.247533 \\
Prob(F-statistic) & 0.000000 & & & \\
\hline \hline \multicolumn{5}{c}{} \\
\hline \hline
\end{tabular}

Gambar 2. Hasil perhitungan FEM

Persamaan hasil regresi data panel dengan metode fixed effect :

$$
\begin{gathered}
\mathrm{PPM}=1969,901-0,122967 \mathrm{X}_{1}-0,004468 \mathrm{X}_{2}-0,162602 \mathrm{X}_{3}+7,897796 \mathrm{X}_{4}+ \\
0,029268 \mathrm{X}_{5}
\end{gathered}
$$




\begin{tabular}{lrlrr}
\hline \hline R-squared & 0.071395 & Mean dependentvar & 2016.000 \\
Adjusted R-5quared & 0.042193 & S.D. dependent var & 1.418519 \\
SE of regression & 1.388270 & Sum squared resid & 306.4397 \\
F-statistic & 2.444911 & Durbin-Watson stat & 0.489074 \\
Prob(F-statistic) & 0.036363 & & & \\
\hline \hline \multicolumn{5}{c}{} \\
\hline \hline
\end{tabular}

Gambar 3. Hasil perhitungan REM

Persamaan hasil regresi data panel dengan metode random effect :

$$
\begin{gathered}
P P M=2015,098+0,002699 X_{1}-0,047516 X_{2}-0,017917 X_{3}+0,448785 X_{4}- \\
0,082898 X_{5}
\end{gathered}
$$

\section{Memilih Model}

Setelah ketiga jenis model sudah dilakukan analisisnya, berikutnya adalah melakukan pengujian untuk memilih salah satu dari ketiga model tersebut.

Uji chow dilakukan untuk melihat model manakah yang lebih tepat, model common effect atau fixed effect model dengan hipotesis sebagai berikut :

H0 : Common Effect Model

H1 : Fixed Effect Model

Jika nilai prob. > 0,05 (H0 diterima)

Jika nilai prob. $<0,05$ (H1 ditolak)

Perhitungan Uji Chow dilakukan dengan program Eviews9 dan didapatkan nilai prob cross section $\mathrm{F}$ sebesar 0,0000 dan nilai chi square sebesar 0,0000. Dan hasil tersebut menunjukkan bahwa nilai prob. $<0,05$ yang berarti $\mathrm{H} 0$ ditolak, maka $\mathrm{H} 1$ diterima yang artinya model fixed effect lebih baik dari pada model common effect.

Uji Hausman digunakan untuk memilih manakah yang lebih tepat antara model random effect atau model fixed effect, dengan hipotesis sebagai berikut :

H0 : Random Effect Model

H1 : Fixed Effect Model

Jika nilai prob. > 0,05 (H0 diterima)

Jika nilai prob. < 0,05 (H1 ditolak) 
Perhitungan Uji Hausman dilakukan dengan program Eviews9 dan didapatkan nilai prob. sebesar 0,0000 hal ini berarti nilai prob. $<0,05$ yang menunjukkan bahwa $\mathrm{H} 0$ ditolak dan $\mathrm{H} 1$ diterima. Hal ini menjelaskan bahwa regresi dengan model fixed effect lebih baik daripada regresi menggunakan model random effect. Sehingga dalam penelitian ini metode regresi data panel yang digunakan adalah fixed effect model.

\section{Uji Signifikansi}

Uji ini terdiri dari Uji F, Uji t, dan Koefisien Determinasi. Perhitungan uji-uji ini dilakukan dengan Eviews9. Uji F dilakukan untuk melihat baik tidaknya model secara simultan. Nilai uji $\mathrm{F}$ adalah $0,000000(<0,05)$ yang artinya secara simultan variabel independen (PDRB, angka melek huruf, rata-rata lama sekolah, tingkat pengangguran terbuka, indeks pembangunan manusia) berpengaruh signifikan terhadap variabel dependen (tingkat kemiskinan di Indonesia tahun 2015-2019).

Uji t bertujuan melihat baik tidaknya model secara parsial. Hasilnya adalah persamaan regresi data panel sebagai berikut :

$\mathrm{PPM}=1969,901-0,122967 \mathrm{X}_{1}-0,004468 \mathrm{X}_{2}-0,162602 \mathrm{X}_{3}+7,897796 \mathrm{X}_{4}+0,029268$ $\mathrm{X}_{5}$

Setelah dilakukan pengujian data dengan menggunakan taraf signifikansi 5\% dari uji t didapatkan hasil penelitian bahwa secara parsial variabel PDRB berpengaruh negatif terhadap kemiskinan, variabel angka melek huruf tidak berpengaruh terhadap kemiskinan, variabel rata-rata lama sekolah tidak berpengaruh terhadap kemiskinan,variabel tingkat pengangguran terbuka berpengaruh positif terhadap kemiskinan, dan variabel indeks pembangunan manusia tidak berpengaruh terhadap kemiskinan di Indonesia.

Koefisien Determinasi digunakan untuk melihat seberapa besar kontribusi variabel independen dengan variabel dependen. Hasilnya adalah variabel independen (PDRB, angka melek huruf, rata-rata lama sekolah, tingkat pengangguran terbuka, indeks pembangunan manusia) memiliki kontribusi sebesar $89 \%$ terhadap perubahan variabel dependen (tingkat kemiskinan), sisanya $11 \%$ dijelaskan oleh faktor lain. Karena nilai $\mathrm{R}^{2}$ yang didapat dalam penelitian ini mendekati angka 1 , berarti model tersebut dikatakan baik karena hubungan antara variabel dependen dengan variabel independen semakin erat.

Dalam penelitian ini, model yang dipilih adalah model efek tetap dengan persamaan sebagai berikut :

$\mathrm{Y}_{i t}=-4.484227 \mathrm{P}_{1}\left(-0.122967 \mathrm{X}_{1}-0.004468 \mathrm{X}_{2}-0.162602 \mathrm{X}_{3}+7.897796 \mathrm{X}_{4}+\right.$ $\left.0.029268 \mathrm{X}_{5}\right)-7.873041 \mathrm{P}_{2}\left(-0.122967 \mathrm{X}_{1}-0.004468 \mathrm{X}_{2}-0.162602 \mathrm{X}_{3}+7.897796 \mathrm{X}_{4}\right.$ $\left.+0.029268 \mathrm{X}_{5}\right)-4.033447 \mathrm{P}_{3}\left(-0.122967 \mathrm{X}_{1}-0.004468 \mathrm{X}_{2}-0.162602 \mathrm{X}_{3}+7.897796\right.$ $\left.\mathrm{X}_{4}+0.029268 \mathrm{X}_{5}\right)-4.509556 \mathrm{P}_{4}\left(-0.122967 \mathrm{X}_{1}-0.004468 \mathrm{X}_{2}-0.162602 \mathrm{X}_{3}+\right.$ $\left.7.897796 X_{4}+0.029268 X_{5}\right)+0.163794 P_{5}\left(-0.122967 X_{1}-0.004468 X_{2}-0.162602 X_{3}\right.$ $\left.+7.897796 \mathrm{X}_{4}+0.029268 \mathrm{X}_{5}\right)+3.169570 \mathrm{P}_{6}\left(-0.122967 \mathrm{X}_{1}-0.004468 \mathrm{X}_{2}-0.162602\right.$ $\left.\mathrm{X}_{3}+7.897796 \mathrm{X}_{4}+0.029268 \mathrm{X}_{5}\right)-0.448159 \mathrm{P}_{7}\left(-0.122967 \mathrm{X}_{1}-0.004468 \mathrm{X}_{2}-\right.$ 
$\left.0.162602 \mathrm{X}_{3}+7.897796 \mathrm{X}_{4}+0.029268 \mathrm{X}_{5}\right)+4.507769 \mathrm{P}_{8}\left(-0.122967 \mathrm{X}_{1}-0.004468 \mathrm{X}_{2}\right.$ $\left.-0.162602 X_{3}+7.897796 X_{4}+0.029268 X_{5}\right)+2.919326 P_{9}\left(-0.122967 X_{1}-0.004468\right.$ $\left.\mathrm{X}_{2}-0.162602 \mathrm{X}_{3}+7.897796 \mathrm{X}_{4}+0.029268 \mathrm{X}_{5}\right)-13.42790 \mathrm{P}_{10}\left(-0.122967 \mathrm{X}_{1}-\right.$ $\left.0.004468 \mathrm{X}_{2}-0.162602 \mathrm{X}_{3}+7.897796 \mathrm{X}_{4}+0.029268 \mathrm{X}_{5}\right)-22.75102 \mathrm{P}_{11}(-0.122967$ $\left.\mathrm{X}_{1}-0.004468 \mathrm{X}_{2}-0.162602 \mathrm{X}_{3}+7.897796 \mathrm{X}_{4}+0.029268 \mathrm{X}_{5}\right)+0.841257 \mathrm{P}_{12}(-$ $\left.0.122967 \mathrm{X}_{1}-0.004468 \mathrm{X}_{2}-0.162602 \mathrm{X}_{3}+7.897796 \mathrm{X}_{4}+0.029268 \mathrm{X}_{5}\right)+7.744731 \mathrm{P}_{13}$ $\left(-0.122967 \mathrm{X}_{1}-0.004468 \mathrm{X}_{2}-0.162602 \mathrm{X}_{3}+7.897796 \mathrm{X}_{4}+0.029268 \mathrm{X}_{5}\right)-7.220996$ $\mathrm{P}_{14}\left(-0.122967 \mathrm{X}_{1}-0.004468 \mathrm{X}_{2}-0.162602 \mathrm{X}_{3}+7.897796 \mathrm{X}_{4}+0.029268 \mathrm{X}_{5}\right)+$ $6.581351 \mathrm{P}_{15}\left(-0.122967 \mathrm{X}_{1}-0.004468 \mathrm{X}_{2}-0.162602 \mathrm{X}_{3}+7.897796 \mathrm{X}_{4}+0.029268\right.$ $\left.\mathrm{X}_{5}\right)-3.499362 \mathrm{P}_{16}\left(-0.122967 \mathrm{X}_{1}-0.004468 \mathrm{X}_{2}-0.162602 \mathrm{X}_{3}+7.897796 \mathrm{X}_{4}+\right.$ $\left.0.029268 \mathrm{X}_{5}\right)-4.022960 \mathrm{P}_{17}\left(-0.122967 \mathrm{X}_{1}-0.004468 \mathrm{X}_{2}-0.162602 \mathrm{X}_{3}+7.897796\right.$ $\left.\mathrm{X}_{4}+0.029268 \mathrm{X}_{5}\right)+10.12888 \mathrm{P}_{18}\left(-0.122967 \mathrm{X}_{1}-0.004468 \mathrm{X}_{2}-0.162602 \mathrm{X}_{3}+\right.$ $\left.7.897796 \mathrm{X}_{4}+0.029268 \mathrm{X}_{5}\right)+10.41716 \mathrm{P}_{19}\left(-0.122967 \mathrm{X}_{1}-0.004468 \mathrm{X}_{2}-0.162602\right.$ $\left.\mathrm{X}_{3}+7.897796 \mathrm{X}_{4}+0.029268 \mathrm{X}_{5}\right)+7.722065 \mathrm{P}_{20}\left(-0.122967 \mathrm{X}_{1}-0.004468 \mathrm{X}_{2}-\right.$ $\left.0.162602 \mathrm{X}_{3}+7.897796 \mathrm{X}_{4}+0.029268 \mathrm{X}_{5}\right)-0.809634 \mathrm{P}_{21}\left(-0.122967 \mathrm{X}_{1}-0.004468\right.$ $\left.\mathrm{X}_{2}-0.162602 \mathrm{X}_{3}+7.897796 \mathrm{X}_{4}+0.029268 \mathrm{X}_{5}\right)+1.029330 \mathrm{P}_{22}\left(-0.122967 \mathrm{X}_{1}-\right.$ $\left.0.004468 X_{2}-0.162602 X_{3}+7.897796 X_{4}+0.029268 X_{5}\right)-9.851562 P_{23}(-0.122967$ $\left.\mathrm{X}_{1}-0.004468 \mathrm{X}_{2}-0.162602 \mathrm{X}_{3}+7.897796 \mathrm{X}_{4}+0.029268 \mathrm{X}_{5}\right)-7.258544 \mathrm{P}_{24}(-$ $\left.0.122967 X_{1}-0.004468 X_{2}-0.162602 X_{3}+7.897796 X_{4}+0.029268 X_{5}\right)+0.828209 P_{25}$ $\left(-0.122967 X_{1}-0.004468 X_{2}-0.162602 X_{3}+7.897796 X_{4}+0.029268 X_{5}\right)+1.661607$ $\mathrm{P}_{26}\left(-0.122967 \mathrm{X}_{1}-0.004468 \mathrm{X}_{2}-0.162602 \mathrm{X}_{3}+7.897796 \mathrm{X}_{4}+0.029268 \mathrm{X}_{5}\right)-$ $1.452911 \mathrm{P}_{27}\left(-0.122967 \mathrm{X}_{1}-0.004468 \mathrm{X}_{2}-0.162602 \mathrm{X}_{3}+7.897796 \mathrm{X}_{4}+0.029268\right.$ $\left.\mathrm{X}_{5}\right)+9.511189 \mathrm{P}_{28}\left(-0.122967 \mathrm{X}_{1}-0.004468 \mathrm{X}_{2}-0.162602 \mathrm{X}_{3}+7.897796 \mathrm{X}_{4}+\right.$ $\left.0.029268 \mathrm{X}_{5}\right)+7.405572 \mathrm{P}_{29}\left(-0.122967 \mathrm{X}_{1}-0.004468 \mathrm{X}_{2}-0.162602 \mathrm{X}_{3}+7.897796\right.$ $\left.\mathrm{X}_{4}+0.029268 \mathrm{X}_{5}\right)-7.143885 \mathrm{P}_{30}\left(-0.122967 \mathrm{X}_{1}-0.004468 \mathrm{X}_{2}-0.162602 \mathrm{X}_{3}+\right.$ $\left.7.897796 \mathrm{X}_{4}+0.029268 \mathrm{X}_{5}\right)-3.719075 \mathrm{P}_{31}\left(-0.122967 \mathrm{X}_{1}-0.004468 \mathrm{X}_{2}-0.162602\right.$ $\left.\mathrm{X}_{3}+7.897796 \mathrm{X}_{4}+0.029268 \mathrm{X}_{5}\right)+11.67763 \mathrm{P}_{32}\left(-0.122967 \mathrm{X}_{1}-0.004468 \mathrm{X}_{2}-\right.$ $\left.0.162602 X_{3}+7.897796 X_{4}+0.029268 X_{5}\right)+16.19683 P_{33}\left(-0.122967 X_{1}-0.004468\right.$ $\left.\mathrm{X}_{2}-0.162602 \mathrm{X}_{3}+7.897796 \mathrm{X}_{4}+0.029268 \mathrm{X}_{5}\right)$

\section{PEMBAHASAN HASIL PENELITIAN}

Hasil penelitian yang telah dilakukan terkait dengan pengaruh PDRB terhadap kemiskinan di Indonesia didapatkan hasil regresi variabel pertumbuhan ekonomi (PDRB) dengan nilai koefisien sebesar -0.122967 dan nilai probabilitasnya sebesar 0.0028 (< 0.05) maka dapat dinyatakan bahwa PDRB berpengaruh signifikan terhadap kemiskinan. Hubungan negatif antara pertumbuhan ekonomi (PDRB) dengan kemiskinan sesuai dengan harapan adanya efek menetas ke bawah (trickle down effect), dimana pertumbuhan ekonomi diyakini mampu mengatasi masalah-masalah pembangunan antara lain masalah kemiskinan. Pertumbuhan ekonomi menunjukkan peningkatan output secara nasional, output akan meningkat apabila faktor-faktor produksi pembentuknya juga mengalami peningkatan baik secara kualitas maupun kuantitas. Tenaga kerja adalah salah satu faktor produksi yang dibutuhkan dalam meningkatkan output. 
Dari hasil penelitian yang telah dilakukan terkait dengan pengaruh angka melek huruf terhadap kemiskinan di Indonesia diperoleh hasil regresi variabel angka melek huruf dengan nilai koefisien sebesar -0.004468 dan nilai probabilitasnya sebesarnya 0.8155 (> 0.05) maka dapat dinyatakan bahwa angka melek huruf tidak berpengaruh terhadap kemiskinan. Angka melek huruf memiliki korelasi negatif, artinya setiap kenaikan persentase angka melek huruf sebesar $1 \%$ akan menimbulkan turunnya tingkat kemiskinan sebesar 0,158338\% dengan asumsi variabel lainnya konstan. Angka melek huruf merupakan salah satu indikator untuk melihat gambaran kualitas pendidikan di suatu wilayah. Semakin tinggi angka melek huruf, semakin tinggi pula kualitas pendidikan di wilayah tersebut yang berdampak pula pada rendahnya jumlah penduduk miskin.

Dari hasil penelitian diperoleh nilai koefisien variabel rata-rata lama sekolah adalah -0.162602 dan nilai probabilitasnya 0.0865 (> 0.05) maka variabel ini tidak berpengaruh terhadap tingkat kemiskinan. Tidak berpengaruhnya hubungan rata-rata lama sekolah dengan kemiskinan, karena pada era globalisasi sekarang tingkat pendidikan formal seseorang tidak cukup agar terhindar dari kemiskinan karena harus memiliki keahlian/skill yang memadai. Rata-rata lama sekolah merupakan salah satu indikator pendidikan, akan tetapi rata-rata lama sekolah tidak serta merta menurunkan kemiskinan karena produktivitas tidak bergantung pada pendidikan formal melainkan pada teknologi dan keterampilan yang memadai.

Dari hasil regresi pada variabel tingkat pengangguran terbuka, terlihat nilai koefisiennya sebesar 7.897796 dan nilai probabilitasnya $0.0000(<0.05)$ maka variabel ini berpengaruh positif terhadap tingkat kemiskinan. Akan tetapi seharusnya tingkat pengangguran terbuka berpengaruh negatif terhadap kemiskinan. Hal ini berarti kenaikan $1 \%$ pengangguran akan meningkatkan kemiskinan $7.89 \%$. Pemilihan indikator pengangguran berdasar pada kenyataan bahwa indikator tersebut terkait langsung dengan pendapatan dari pekerjaan. Banyak dan beragamnya kebutuhan masyarakat membuat mereka berusaha untuk memenuhi kebutuhannya, hal yang dilakukan adalah bekerja untuk menghasilkan pendapatan. Pendapatan masyarakat mencapai maksimum apabila kondisi tingkat penggunaan tenaga kerja penuh (full employement) dapat terwujud, jika tidak maka akan terjadi pengangguran. Efek buruk dari pengangguran adalah mengurangi tingkat pendapatan masyarakat dan dengan begitu akan memberikan dampak dalam mengurangi tingkat kemakmuran. Semakin turun tingkat kemakmuran masyarakat karena pengangguran tentunya akan meningkatkan peluang terjebak dalam kemiskinan.

Dari hasil regresi pada variabel indeks pembangunan manusia, diketahui bahwa nilai koefisien sebesar 0.029268 dan nilai probabilitasnya sebesar $0.3810(>0.05)$ maka dapat dinyatakan bahwa variabel indeks pembangunan manusia tidak berpengaruh terhadap kemiskinan. Dari hasil ini, menggambarkan bahwa peningkatan indeks pembangunan manusia di Indonesia yang di lihat melalui ketiga aspek yakni pertama, indeks harapan hidupnya. Kedua, pendidikan. Serta yang ketiga, standart hidup layak di Indonesia masih berpengaruh kecil untuk mengentaskan kemiskinan. Berdasarkan pemaparan di atas dapat disimpulkan bahwa pentingnya bagi seseorang untuk menjadi SDM yang berkualitas, pada saat ini menyiapkan SDM berkualitas menjadi semakin 
rumit namun harus dihadapi. Oleh karenanya, pemerintah diharapkan terus mampu meningkatkan ketiga aspek tersebut melalui program-program yang ditujukan untuk peningkatan indeks pembangunan manusia di Indonesia. Seperti malalui peningkatan serta pemerataan pendidikan dan teknologi, peningkatan dan pemerataan pelayanan kesehatan, meluaskan program pelatihan-pelatihan usaha dan memberikan pelatihan yang lebih berkompetitif sehingg dapat menghasilkan tenaga kerja yang lebih mandiri dan mampu bersaing di dunia kerja.

\section{KESIMPULAN}

Variabel PDRB $\left(\mathrm{X}_{1}\right)$ berpengaruh negatif terhadap kemiskinan dan tingkat pengangguran terbuka $\left(\mathrm{X}_{4}\right)$ berpengaruh positif terhadap kemiskinan di Indonesia tahun 2015-2019. Sedangkan variabel angka melek huruf $\left(X_{2}\right)$, rata-rata lama sekolah $\left(X_{3}\right)$, dan indeks pembangunan manusia $\left(\mathrm{X}_{5}\right)$ tidak berpengaruh terhadap tingkat kemiskinan di Indonesia tahun 2015-2019. Provinsi yang terdampak negatif (kemiskinan berkurang) faktor-faktor kemiskinan yaitu Provinsi DKI Jakarta sebesar 22.75\%, Provinsi Kep. Riau sebesar 13.42\%, dan Provinsi Kalimantan Timur sebesar 9.85\%. Sedangkan yang terdampak positif (kemiskinan meningkat) faktor-faktor kemiskinan yaitu Provinsi Papua sebesar 16.19\%, Provinsi Papua Barat sebesar 11.67\%, dan Provinsi Nusa Tenggara Timur sebesar $10.41 \%$.

\section{DAFTAR PUSTAKA}

Adhi Saputra, Wishnu. 2011. "Analisis Pengaruh Jumlah Penduduk, PDRB, IPM, Pengangguran Terhadap Tingkat Kemiskinan di Kabupaten/Kota Jawa Tengan”, Skripsi (Semarang: Universitas Diponegoro).

Al Jundi, Musa. 2014. “Analisis Faktor yang Mempengaruhi Tingkat Kemiskinan Provinsi-Provinsi di Indonesia”, Skripsi (Semarang: Fakultas Ekonomika dan Bisnis Universitas Diponegoro).

Baltagi, B. H. 2005. Econometrics Analysis of Data Panel. Third Edition. John Wiley \& Sons Ltd., Chinester.

Baltagi, B. H. 2008. Econometric. Fourt Edition. Springer Verlag, Berlin Heidlberg.

Fairuz, Annisa Amalia. 2017. "Pengaruh Rasio Solvabilitas, Rasio Pasar, Inflasi, dan Kurs Terhadap Return Saham Syari'ah (Studi Pada Saham Syariah Yang Bergantung Dalam Kelompok ISSI Pada Sektor Industri Tahun 2011-2015)”. Skripsi (Jakarta: Fakultas Ekonomi \& Bisnis Universitas Negeri Islam Syarif Hidayatullah).

Fitrianingsih. 2007. "Model Efek Tetap dan Model Efek Acak pada Data Longitudinal”. Skripsi (Malang: Fakultas Sains \& Teknologi Universitas Brawijaya).

Gujarati, Damodar N. 1988. Ekonometrika Dasar. Jakarta : Erlangga.

Hutabarat, Desty. 2018. "Pengaruh Angka Harapan Hidup, Rata-Rata Lama Sekolah, Pengeluaran Riil Per Kapita, Pertumbuhan Ekonomi, dan Pengangguran Terhadap 
Jumlah Penduduk Miskin di Provinsi Sumatera Utara”. Skripsi (Sumatera Utara: Fakultas Ekonomi \& Bisnis Universitas Sumatera Utara)

J. Supranto, M. A. 1998. Statistik Teori dan Aplikasi Edisi Kelima. Jakarta : Erlangga.

Nachrowi, D. N. \& Usman, H. 2006. Pendekatan Populer dan Praktis Ekonometrika untu Analisis Ekonomi dan Keuangan. Lembaga Penerbit FE UI, Jakarta.

Oktavia Fitri, Cenita. 2019. “Analisis Faktor-Faktor Yang Mempengaruhi Tingkat Kemiskinan Kabupaten/Kota di Provinsi Lampung Dalam Persfektif Ekonomi Islam Tahun 2011-1018”, Skripsi (Lampung: Fakultas Ekonomi dan Bisnis Islam Universitas Islam Negeri Raden Intan).

Ra'yan, Ismi. 2018. “Analisis Regresi Data Panel Pada Faktor-Faktor yang Mempengaruhi Tingkat Kemiskinan Provinsi Sulawesi Selatan Tahun 2011-2015”, Skripsi (Makassar: Fakultas Sains \& Teknologi Universitas Islam Alauddin Makassar).

Widodo, Edy. 2019. “Analisis Regresi Pada Kasus Kemiskinan di Indonesia”, Jurnal (Yogyakarta: Program Studi Statistika Universitas Islam Indonesia).

Yuwita Sari, Anes. 2017. "Metode Regresi Data Panel Dalam Pemodelan Tingkat Kemiskinan Provinsi Lampung Tahun 2010-2013”. Skripsi (Lampung: Fakultas Matematika dan Ilmu Pengetahuan Alam Universitas Lampung). 